\title{
Synthesis and Characterization of Mn doped ZnO Nanoparticles and Degradation of Pyridine in a Batch Reactor Using: Taguchi Experimental Designing \& Molecular Mechanic Simulation
}

\author{
Maryam Otadi ${ }^{1}$ *, Ziba PanahiShayegh ${ }^{1}$, Majid Monajjemi ${ }^{1,}$ * (D) \\ 1 Department of Chemical engineering, Central Tehran Branch, Islamic Azad University, Tehran, Iran \\ * Correspondence: maryamotadi@gmail.com (M.O.); maj.monajjemi@iauctb.ac.ir (M.M.);
}

Scopus Author ID 670181068

Received: 30.12.2020; Revised: 24.01.2021; Accepted: 26.01.2021; Published: 30.01.2021

\begin{abstract}
In this study, the review and synthesis of $\mathrm{ZnO}$ and $\mathrm{Mn}$-doped $\mathrm{ZnO}$ are discussed. $\mathrm{ZnO}$ is a substance that, because of its high potential in various applications such as the manufacture of solar cells, gas sensors, chemical absorbents, optical and electrical instruments, etc., is taken into consideration. $\mathrm{ZnO}$ and various levels of manganese (Mn) - doped $\mathrm{ZnO}$ were synthesized by the Solgel method. Characterization was carried out by XRD and SEM. Using Taguchi experimental design by software Qualitek-4. Optimum is determined, and this case was investigated by varying the time parameter. Photodegradation of Pyridine under visible light in a batch reactor by un-doped and doped $\mathrm{ZnO}$. The optimal concentration of $6 \% \mathrm{Mn}$ and calcined at $350^{\circ} \mathrm{C}$ for $3 \mathrm{hr}$ was introduced. The curve map of broadened partial DOS (PDOS) and overlap DOS (OPDOS) for 6\% and 10\% Mn-doped ZnO have also been plotted and comprised of experimental data.
\end{abstract}

Keywords: $\mathrm{ZnO}$; sol-gel; manganese doping; nano-particles; photocatalytic degradation; Taguchi.

(c) 2021 by the authors. This article is an open-access article distributed under the terms and conditions of the Creative Commons Attribution (CC BY) license (https://creativecommons.org/licenses/by/4.0/).

\section{Introduction}

Zinc oxide is a semiconducting material with a hexagonal crystalline structure known as the wurtzite structure. It is a semiconductor material with a bandgap of approximately 3,2$3,37 \mathrm{eV}$ at $300 \mathrm{~K}$, and the bandgap is wide [1-4]. It consists of a crystal lattice defined by the lattice parameters $a$ and $c$ and a basis containing 4 atoms as illustrated in scheme 1. Zinc oxide is a typical semiconductive and piezoelectric material with applications in electronics, optoelectronics, sensors, and energy conversions. According to reports, instead of titanium dioxide, zinc oxide is a good economical alternative. It has a good photocatalytic ability to remove organic contaminants [5-6]. One-dimensional nanostructures of $\mathrm{ZnO}$ are very important semiconductor building blocks with unique and novel physical and chemical properties. Various morphologies of $\mathrm{ZnO}$ nanostructures, such as nanowire arrays, nanorods, nanobelts, and nanotubes, have been synthesized using physical, chemical, and electrochemical methods. Pure, undoped $\mathrm{ZnO}$ photocatalysts have limited applications. It consists of a crystal lattice defined by the lattice parameters a and $\mathrm{c}$ and a basis containing 4 atoms as illustrated in scheme 1 . The wurtzite surfaces are typically described in a four-vector basis - three in the (xy) plane defining the hexagonal geometry and one along the z-axis as seen in scheme1. The ions are doped to achieve some desired properties like wide or narrow bandgap, increases in 
optical absorbance and ferromagnetism, etc. [7]. Mn-doped $\mathrm{ZnO}$ has been synthesized by various techniques [8-16]. On the nanoscale, $\mathrm{ZnO}$ strongly favors crystalline growth in the cdirection, resulting in the formation of many different nanostructures such as nanotubes and nanorods nanobelts, and nanowire. The most studied is the hexagonal nanowire. The nanowires, synthesized by a physical vapor deposition (PVD) process, are very uniform in appearance, being single-crystalline rods. In this study, $\mathrm{ZnO}$ and $\mathrm{Mn}$-doped $\mathrm{ZnO}$ crystals were synthesized using the sol-gel technique. This method is the easiest and best way to synthesis nanoparticles. Pyridine is a toxic organic compound found in some industries' wastewater, such as the food and pharmaceutical industries. Pyridine is used in the synthesis of vitamins and medicines, herbicides, etc. To evaluate the photocatalytic ability to remove pyridine has been studied [17]. Synthesis of $\mathrm{ZnO}$ and $\mathrm{Mn}$-doped $\mathrm{ZnO}$ was carried out by the sol-gel method. Taguchi method of experimental design is performed by Qualitek-4 software. Optimum is determined to remove pyridine in the batch reactor under visible light. The missing absorbance of visible light makes this material one of the best transition metal oxide nanoparticles [18-19].

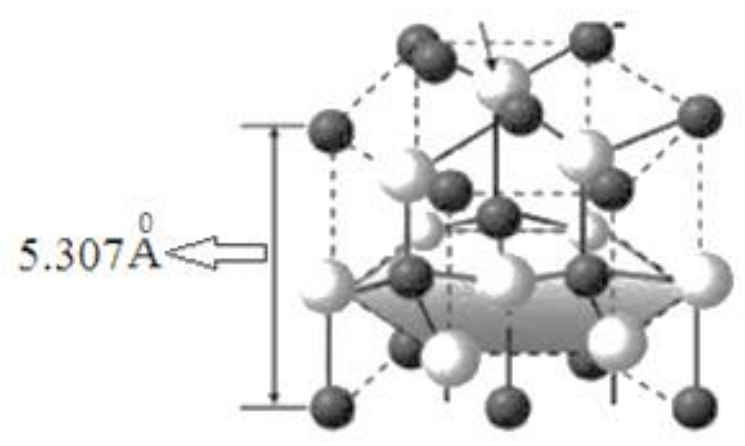

Wurtize structure

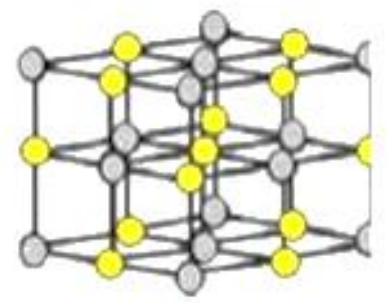

Rock Structure

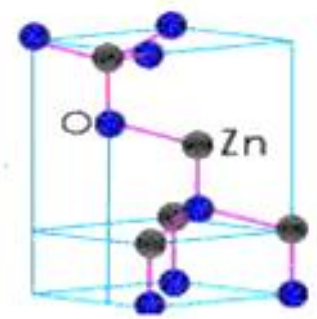

Blende
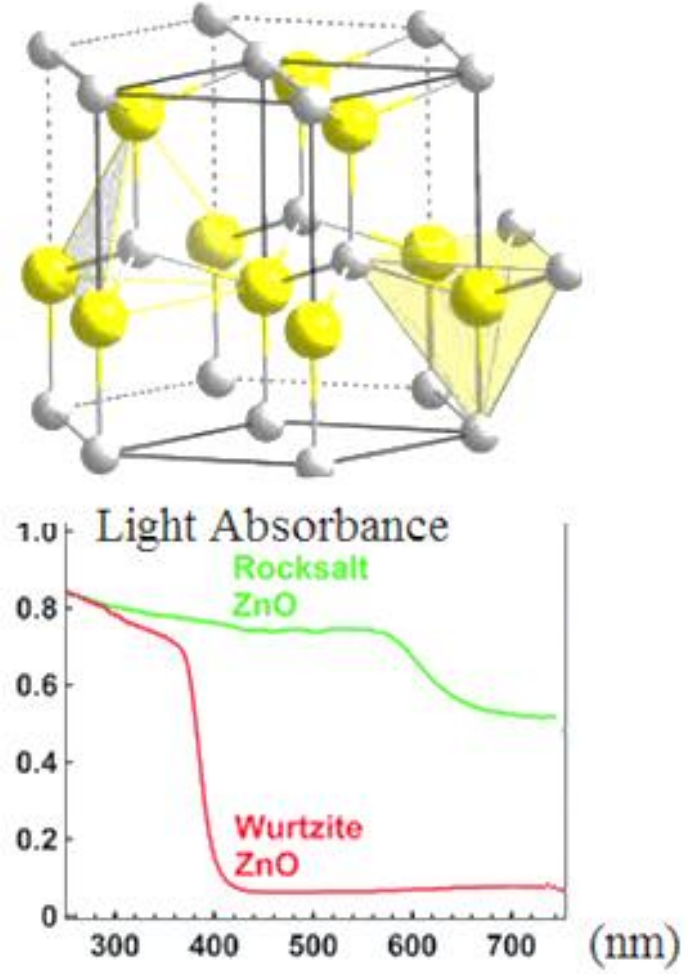

Scheme 1. Zinc oxide in various structures.

\section{Materials and Methods}

\subsection{Materials \& preparation.}

$\mathrm{Zn}\left(\mathrm{CH}_{3} \mathrm{COO}\right) .2 \mathrm{H}_{2} \mathrm{O}$ (99\%, Merck), $\mathrm{Na}_{2} \mathrm{CO}_{3}$ (99.5\%, Merk), $\mathrm{n}\left(\mathrm{CH}_{3} \mathrm{COO}\right)_{2} .4 \mathrm{H}_{2} \mathrm{O}$ (99.99\%, Merk), pyridine (99\%, Merk), deionised water, were used without further purification. The synthesis of $\mathrm{ZnO}$ and $\mathrm{Mn}$-doped $\mathrm{ZnO}$ by the sol-gel method is presented. This study's synthesis method is similar to Article 20 has been in references with a slight change. A typical synthesis of undoped $\mathrm{ZnO}, 13.5 \mathrm{~g}$ of $\mathrm{Zn}\left(\mathrm{CH}_{3} \mathrm{COO}\right) .2 \mathrm{H}_{2} \mathrm{O}$ and $6.5 \mathrm{~g}$ of $\mathrm{Na}_{2} \mathrm{CO}_{3}$ were separately dissolved in $50 \mathrm{ml}$ of deionized water. $\mathrm{Next}$, the $\mathrm{Na}_{2} \mathrm{CO}_{3}$ solution to form white precipitates. Precipitates on the filter paper are washed with deionized water to remove reaction by-products until the TDS of the supernatant becomes less than $100 \mathrm{ppm}$. The 
separated precipitates were dried in an oven $80{ }^{\circ} \mathrm{C}$ and then heat-treated at $350^{\circ} \mathrm{C}$ for $1 \mathrm{hr}$. A solid mixture of 2, 4, and 6 mole $\% \mathrm{Mn}\left(\mathrm{CH}_{3} \mathrm{COO}\right)_{2} .4 \mathrm{H}_{2} \mathrm{O}$ was dissolved in $50 \mathrm{ml}$ of deionized water and then mixed with an aqueous solution of $\mathrm{Na}_{2} \mathrm{CO}_{3}$, followed by the same procedures for undoped $\mathrm{ZnO}$ (9). According to the experimental design, time and the calcined temperature is set to.

\subsection{Characterization.}

X-ray Diffraction (XRD) analysis of the photocatalysts for structural characterization was carried out using a Philips Diffractometer. The samples' chemical composition and morphology were carried out using a scanning electron microscope (SEM), model Leo 440i. Crystal size measured by equation Williamson - Hall has been calculated. The optical absorption spectra were obtained using a (model) UV-Vis spectrometer. 60ppm concentration of pyridine was prepared using deionized water. Magnetic stirring at a speed of $200 \mathrm{rpm}$ was applied to mate the suspension solution during the reaction. The photoreactor is located in a tin-Cylinder, and the Mixing chamber is made of Pyrex. A tungsten lamp (300 Watt) was used as a light source. Pyridine was used as a probe molecule to evaluate the photocatalytic activity of undoped and doped $\mathrm{ZnO}$ nanoparticles in response to visible light irradiation of pyridine's characteristic optical absorption peak $256 \mathrm{~nm}$ was chosen to monitor the photocatalytic degradation process, for each set of experiments, $200 \mathrm{ml}$ of a standard pyridine solution (60 ppm) mixed with $1 \mathrm{~g} / \mathrm{l}$ of each of the powders. The suspension was stirred in the dark for 30 minutes to ensure the establishment of absorption and desorption equilibrium of pyridine on the par ticle surface. Next, the solution's $\mathrm{pH}$ is adjusted by a device $\mathrm{pH}$ meter and Concentrated $\mathrm{HCl}$ acid to reach the level $6.8 \pm 0.2(21)$. Then the solution is transferred into the reactor and stays under visible light for 30 minutes.

\section{Results and Discussion}

Taguchi method of experimental design is performed by software Qualitek-4. The experiments are considered concentration, time, and temperature factors, and These factors have been studied in three-level. The factors and levels are shown in Table 1.

Table 1. Factors and levels.

\begin{tabular}{l|c|c|c} 
Factor & Level 1 & Level 2 & Level 3 \\
\hline Mn doped $\mathrm{ZnO}$ & $2 \%$ & $4 \%$ & $6 \%$ \\
\hline Temperature & $350^{\circ} \mathrm{C}$ & $450^{\circ} \mathrm{C}$ & $550^{\circ} \mathrm{C}$ \\
\hline Time & $1 \mathrm{hr}$ & $2 \mathrm{hr}$ & $3 \mathrm{hr}$
\end{tabular}

Experiments were designed to help software, suggested array L9, and are given in Table 2.

Table 2. The proposed experiments by software.

\begin{tabular}{l|c|c|c} 
No. & Mn-doped ZnO & Temperature & Time \\
\hline 1 & $2 \%$ & $350^{\circ} \mathrm{C}$ & $1 \mathrm{hr}$ \\
\hline 2 & $2 \%$ & $450^{\circ} \mathrm{C}$ & $2 \mathrm{hr}$ \\
\hline 3 & $2 \%$ & $550^{\circ} \mathrm{C}$ & $3 \mathrm{hr}$ \\
\hline 4 & $4 \%$ & $350^{\circ} \mathrm{C}$ & $2 \mathrm{hr}$ \\
\hline 5 & $4 \%$ & $450^{\circ} \mathrm{C}$ & $3 \mathrm{hr}$ \\
\hline 6 & $4 \%$ & $550^{\circ} \mathrm{C}$ & $1 \mathrm{hr}$ \\
\hline 7 & $6 \%$ & $350^{\circ} \mathrm{C}$ & $3 \mathrm{hr}$ \\
\hline 8 & $6 \%$ & $450^{\circ} \mathrm{C}$ & $1 \mathrm{hr}$ \\
\hline 9 & $6 \%$ & $550^{\circ} \mathrm{C}$ & $2 \mathrm{hr}$
\end{tabular}


The experiment results are shown in Table 3 are repeated three times. The maximum absorption wavelength is $256 \mathrm{~nm}$ it has been found that the results. Maximum absorption at a wavelength of $256 \mathrm{~nm}$ to $\mathrm{ZnO}$ is 3.389(au.).

Table 3. The result of experiments.

\begin{tabular}{l|c|c|c} 
No. & $\begin{array}{c}\text { Result 1 } \\
\text { Absorbance } \\
\text { (au.) }\end{array}$ & $\begin{array}{c}\text { Result2 } \\
\text { Absorbance } \\
\text { (au.) }\end{array}$ & $\begin{array}{c}\text { Result3 } \\
\text { Absorbance } \\
\text { (au.) }\end{array}$ \\
\hline 1 & 3.295 & 3.29 & 3.300 \\
\hline 2 & 3.907 & 3.900 & 3.921 \\
\hline 3 & 3.008 & 3.007 & 3.020 \\
\hline 4 & 3.732 & 3.621 & 3.730 \\
\hline 5 & 2.927 & 2.910 & 2.928 \\
\hline 6 & 3.100 & 3.104 & 3.103 \\
\hline 7 & 2.724 & 2.725 & 2.751 \\
\hline 8 & 3.189 & 3.169 & 3.190 \\
\hline 9 & 3.801 & 3.800 & 3.798
\end{tabular}

Pyridine adsorption by $\mathrm{ZnO}$ and Nano-photocatalysts made according to the design of experiments is shown in Figure 1.

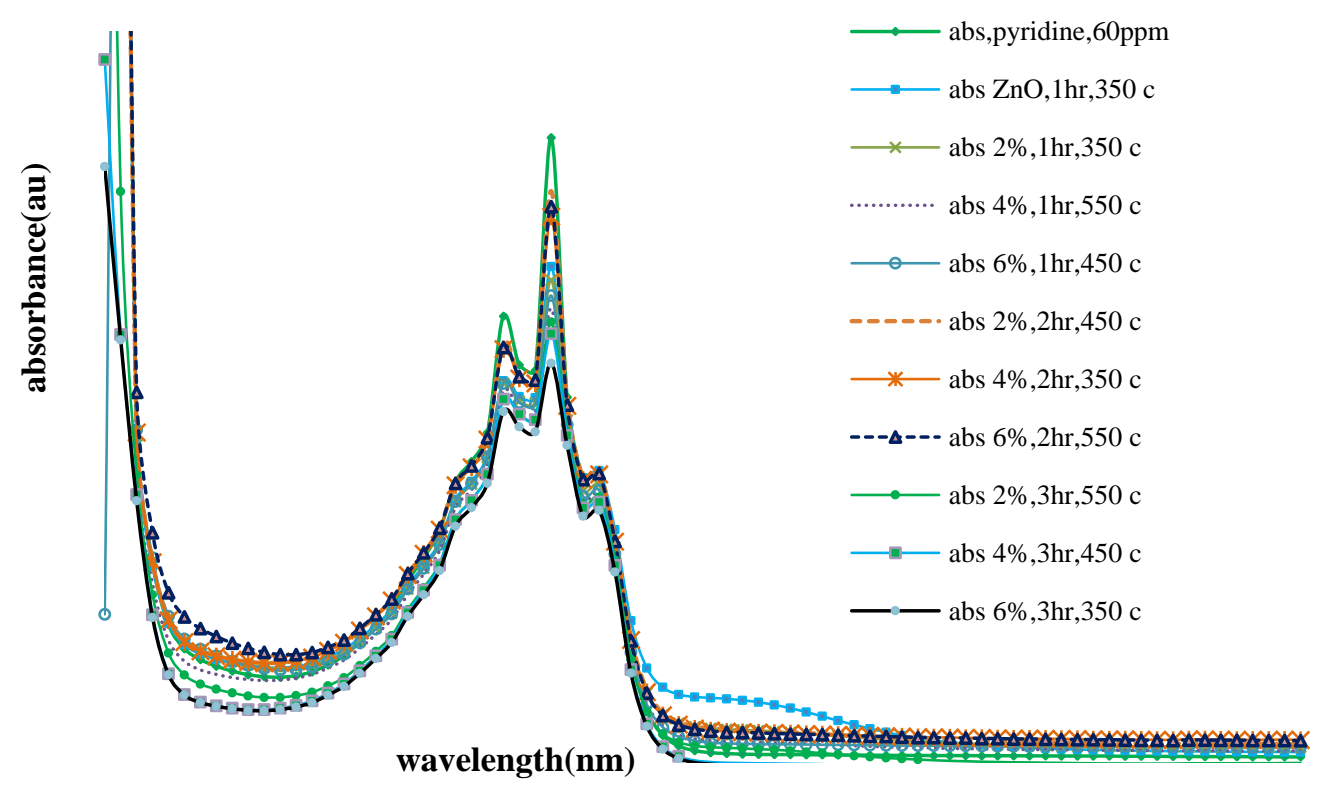

Figure 1. Pyridine adsorption by photocatalysts.

First, the results of the first experiments to test the accuracy of the standard method are investigated. The optimum concentration of $6 \%$, time $3 \mathrm{hr}$ at $350^{\circ} \mathrm{C}$ has been provided by the software. Experiments repeated three times, and then with the help of $\mathrm{S} / \mathrm{N}$ method, optimal conditions have been determined. In this method, the same result is obtained using the standard method. The effect of each factor in Figure 2 (a bar) and Figure 3 (a pie) is shown. As can be seen, the time factor has the greatest effect, and the temperature factor has the least effect. It should be noted that the software design based on the response of less is better Because the absorption rate is less than the ability to remove the photocatalysts. In figure 1 is presented by optimal design of experiments that have the lowest absorption. 


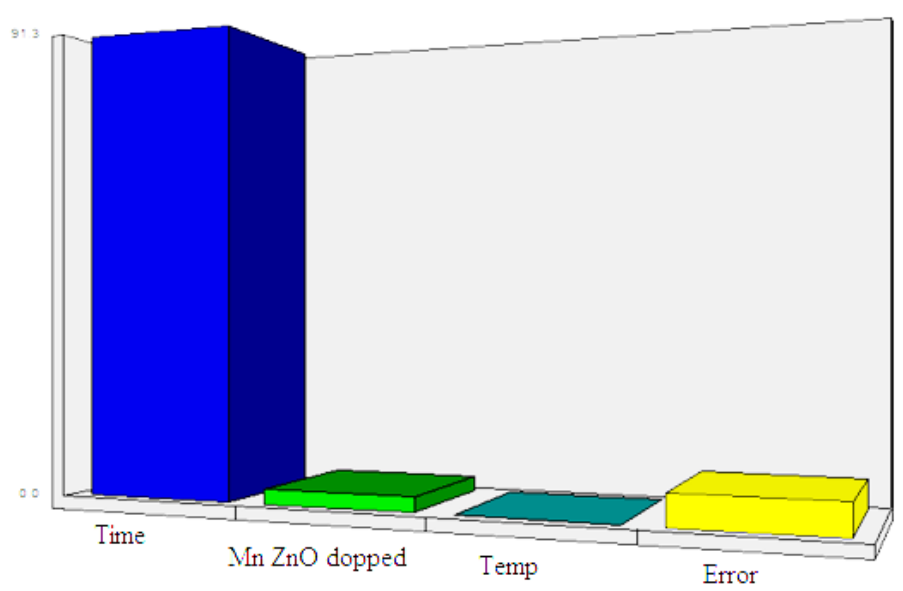

Figure 2. The effect of each factor on a bar graph.
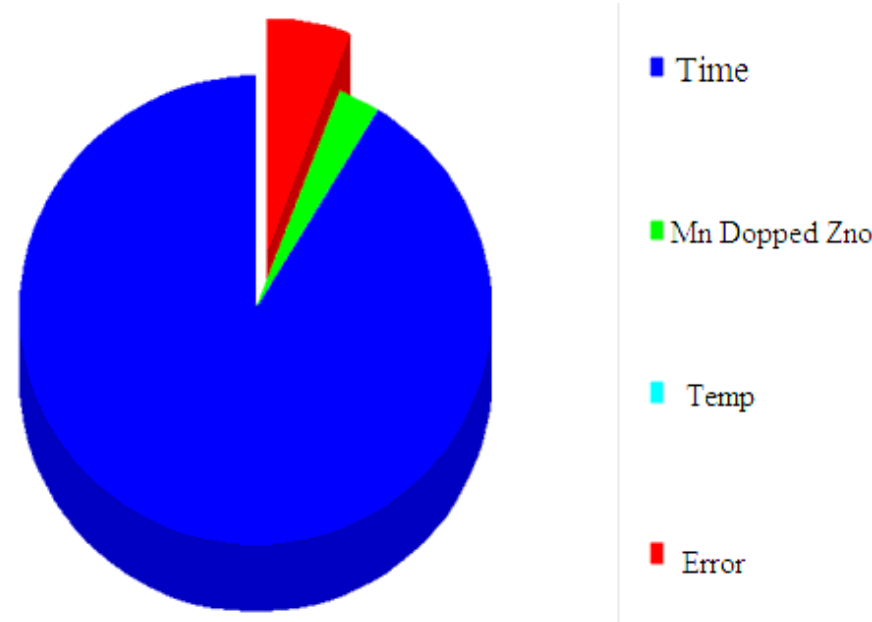

Figure 3. The effect of each factor on a pie graph.

\subsection{Study of optimum.}

The XRD pattern of undoped $\mathrm{ZnO}$ and $\mathrm{Mn}$-doped $\mathrm{ZnO}$ with $6 \% \mathrm{Mn}$, time $3 \mathrm{hr}$ at $350^{\circ} \mathrm{C}$ concentration are presented in figure 4 . The XRD pattern shows only the peaks correspond to the wurtzite crystal structure of $\mathrm{ZnO}$. There is no signature of impurity peaks in the XRD pattern of samples that might belong to the Mn-related secondary phase.

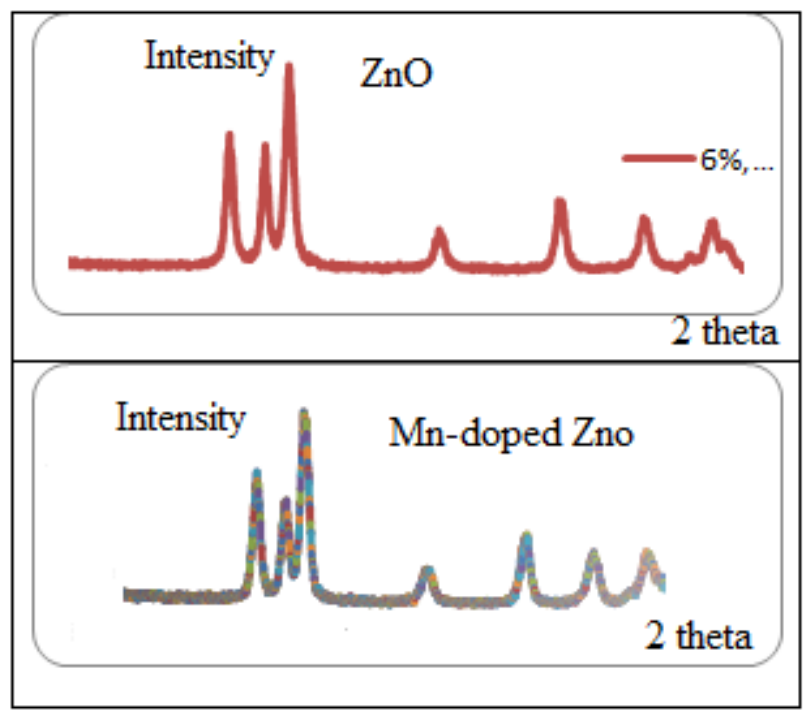

Figure 4. The XRD pattern of undoped $\mathrm{ZnO}$ and $\mathrm{Mn}$-doped $\mathrm{ZnO}$. 
Crystalline particle size is shown in Table 4. In the case of the doped crystal, size increased.

Table 4. Crystalline particle size.

\begin{tabular}{l|c|c} 
Zinc Oxide & $\mathbf{Z n O}$ & $\mathbf{6 \% , 3 \mathbf { h r } , 3 5 0}{ }^{\circ} \mathbf{C}$ \\
\hline Crystallite size $(\mathrm{nm})$ & 13.68 & 16.94 \\
\hline \multicolumn{3}{c}{ Crystalline particle size By changing the time factor } \\
\hline Zinc Oxide & $6 \%, 1 \mathrm{hr}, 350^{\circ}$ & $6 \%, 3 \mathrm{hr}, 350^{\circ} \mathrm{C}$ \\
\multicolumn{3}{c}{$\mathrm{C}$} \\
\hline Crystallite size $(\mathrm{nm})$ & 17.25 & 16.94
\end{tabular}

The SEM image of $6 \%$ Mn-doped $\mathrm{ZnO}$ illustrates the morphology is well ordered. A lower aggregation and better particle size distribution (Figure 5).

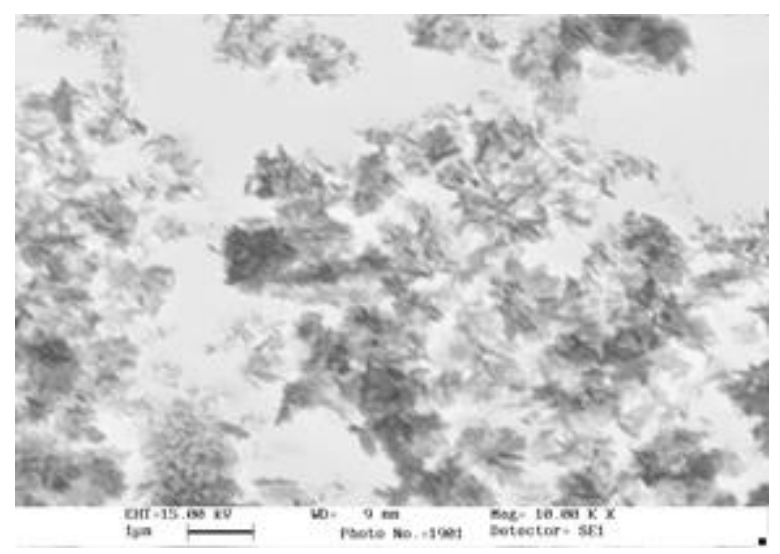

Figure 5. SEM micrograph for $6 \%$ doped $\mathrm{ZnO}$.

\subsection{Times calcined effect in the doped state.}

They have been synthesized to investigate the concentration of $6 \%$ and a temperature of $350{ }^{\circ} \mathrm{C}$ for $1 \mathrm{hr}$. XRD results show that the calcined particle size decreased with increasing time (Table 4). XRD results are similar to previous studies (Figure 6).

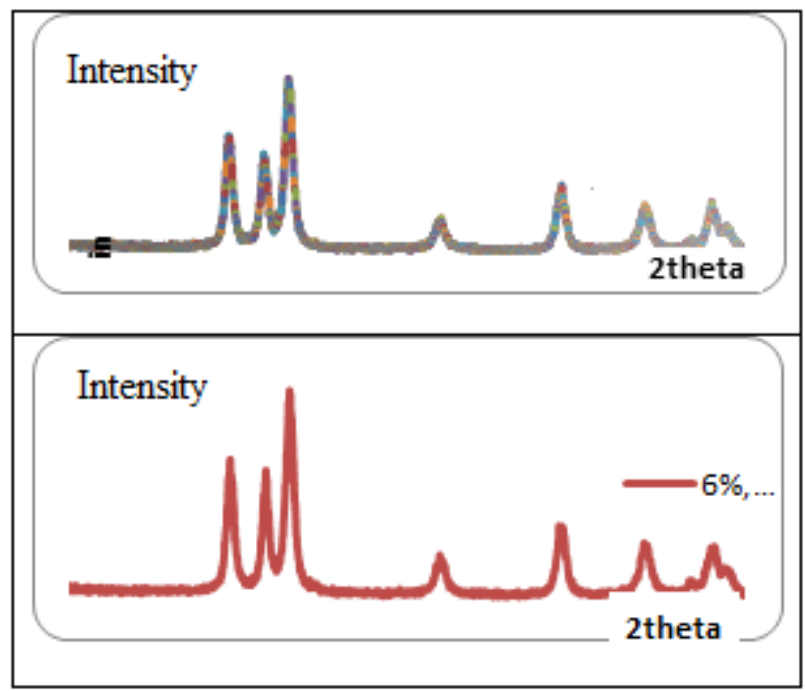

Figure 6. The XRD pattern of $6 \%$ doped $\mathrm{ZnO}$.

\subsection{Modeling and simulation results.}

Our model has been simulated based on our previous works [22-49]. Several new methods have been simulated based on recent works[50-58]. Using Density-of-states (DOS), 
the number of states in a unit energy interval can be presented since energy levels are contiguous. Thus, DOS has been plotted as a curve map due to isolated systems and discrete energy levels. We have considered the DOS graph to analyze the nature of electronic structures over the surfaces. The original total DOS (TDOS) of our system have been calculated via $\operatorname{TDOS}(E)=\sum_{i} \delta\left(E-\varepsilon_{i}\right)$ (1) formula. The eigenvalue " $\varepsilon$ " is a set of single-particle Hamilton, and " $\delta$ " is the Dirac delta function that can be yielded after replacing Gaussian [59-61]. There is another formula as: $G(X)=\frac{1}{c \sqrt{2 \pi}} e^{\frac{-x^{2}}{2 c^{2}}}$ (2) that the FWHM $\left(c=\frac{F W H M}{2 \sqrt{2 \ln 2}}\right)$ (3) stands for "full width at half maximum", an adjustable parameter in a multi-wave function program where the larger FWHM results in a smoother looking TDOS graph, making the analysis to be performed easier. The normalized Lorentzian function is defined as $L(X)=\frac{F W H M}{2 \pi} \frac{1}{x^{2}+0.25 F W H M^{2}}$ Pseudo-Voigt function is weighted as a linear combination of Gaussian function and Lorentzian function [59,60]: $P(x)=w_{\text {gauss }} G(x)+\left(1-w_{\text {gauss }}\right) L(x)(5)$. The curve map of broadened partial DOS (PDOS) and overlap DOS (OPDOS) are valuable for visualizing orbital composition analysis PDOS function of fragment $A$ is defined as: $\operatorname{PDOS}_{A}(E)=\sum_{i} \Xi_{i, A} F(E-$ $\varepsilon_{i}$ ) (6) where $\Xi_{i, A}$ is the composition of fragment "A" in orbital $i$. The OPDOS between fragment " $\mathrm{A}$ " and " $\mathrm{B}$ " is defined as $O P D O S_{A, B}(E)=\sum_{i} X_{A, B}^{i} F\left(E-\varepsilon_{i}\right)(7)$ where $X_{A, B}^{i} A, B$ is the composition of a total cross term between fragment $A$ and $B$ in orbital. Both original and broadened TDOS/PDOS/OPDOS are shown in this study. It is important to note that the height is only meaningful for lines (original data) and not for curves. The left-axis and right-axis correspond to TDOS/PDOS and OPDOS, respectively [59-61]. The graph of gradient map with contour lines type represents the gradient direction of real space function. Since gradients of real space function are needed to be evaluated in our system, we have calculated these contour maps in our works. The vector field map with contour lines is very similar to the last graph type. However, the gradient lines are replaced by arrows, which distribute on grids evenly and represent gradient vectors at corresponding points [59-61]. It can also use filename .wfn instead of filename .fchk to calculate the gradient within the contour map with topology paths of electron density. This type of graph is very useful in Bader's QTAIM analysis. It can also plot the gradient + contour map for any other real space functions supported by Multiwfn [59-61]. The critical points and paths to be portrayed on the graph are needed to do topology analysis. The deformation map of electron density clearly shows us the electron density variation during the formation of the molecule, molecular electron density minus electron densities of each atom in free-state (Fig.5)[62-88].

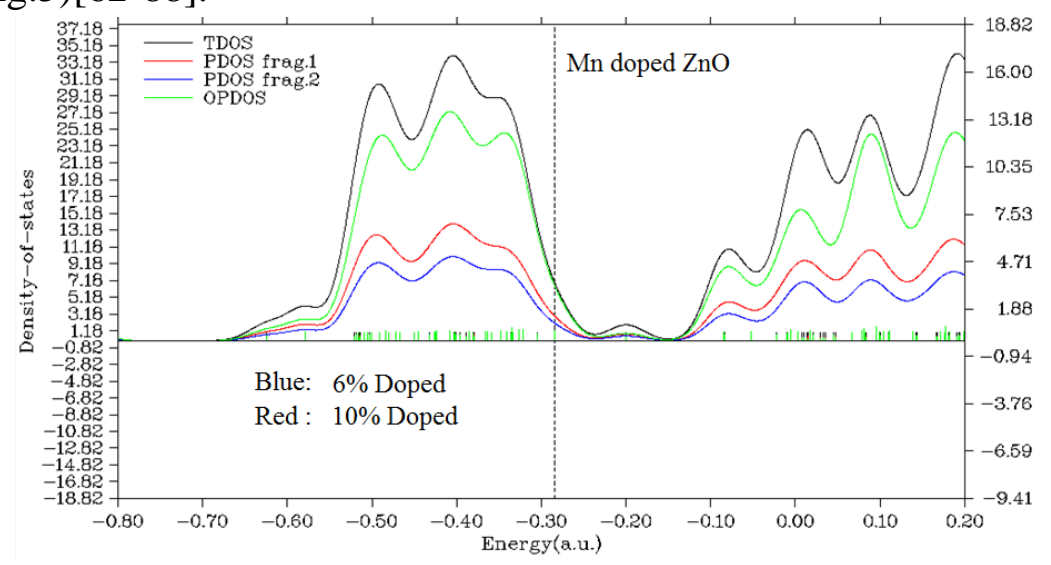

Figure 5. The curve map of broadened partial DOS (PDOS) and overlap DOS (OPDOS) for 6\% and 10\% Mndoped $\mathrm{ZnO}$. 


\section{Conclusions}

Various levels of Mn-doped $\mathrm{ZnO}$ were synthesized by the Sol-gel method. Characterization was carried out by XRD, SEM. In order to evaluate the synthesized photocatalyst, pyridine photodegradation was studied under visible- light. Experimental design with three factors and three levels were Qualitek-4 Software. In conclusion, 6\% Mn-doped $\mathrm{ZnO}$ in $350^{\circ} \mathrm{C}$ and $3 \mathrm{hr}$ is suitable as the best photocatalyst for removing pyridine. According to the results, XRD doped crystalline particle size increased, and Mn-doped $\mathrm{ZnO}$ is suitable for removing pyridine. Finally, the partial DOS (PDOS) and overlap DOS (OPDOS) for $6 \%$ and $10 \% \mathrm{Mn}$-doped $\mathrm{ZnO}$ have been analyzed and comprised of experimental data.

\section{Funding}

This research received no external funding.

\section{Acknowledgments}

Thanks to the Central Tehran Branch, Islamic Azad University, for supporting computational software and all necessary equipment.

\section{Conflicts of Interest}

The authors declare no conflict of interest.

\section{References}

1. Nirmala, M.; Liani, A.A. Structural and optical properties of an undoped and Mn doped ZnO nanocrystalline thin film. Photonics Letters of Poland 2010, 2, 189-191, https://doi.org/10.4302/plp.2010.4.16.

2. Tsuzuki, T.; Robinson, J.S.; Cormick, P.G.M. UV-shielding ceramic nanoparticles synthesised by mechanochemical processing. J. Aus. Ceram. Soc. 2002, 38, 15-19.

3. Ahmad, M.; Pan, C.; Yan, W.; Zhu, J.mEffect of Pb-doping on the morphology, structural and optical properties of $\mathrm{ZnO}$ nano wires synthesized via modified thermal evaporation. Materials science and engineering: $B$ 2010, 174, 55-8.

4. Bak, T.; Nowotny, J.; Rekas, M.; Sorrell, C.C. Photo-electrochemical hydrogen generation from water using solar energy. Materials-related aspect. Int. J. Hydrogen Energy 2002, 27, 1022-27991, https://doi.org/10.1016/S0360-3199(02)00022-8.

5. Daneshvar, N.; Salari, D.; Khataee, A.R. Photocatalytic degradation of azo dye acid red 14 in water: investigation of the effect of operational parameters. Journal of Photochemistry and Photobiology A: Chemistry 2003, 157, 111-116, https://doi.org/10.1016/S1010-6030(03)00015-7.

6. Linsebigler, A.L.; Lu, G.; Yates Jr, J.T.J.C.R. Photocatalysis on TiO2 surfaces: principles, mechanisms, and selected results. Chem. Rev.1995, 95, 735-758.

7. Ezema, F.; Nwankwo, U. Effect of concentration of Mn dopant ions on the structural and optical properties of zinc oxide crystals. Digest Journal of Nanomaterials and Biostructures 2011, 6, 1, 271-278

8. Pazhanivelu, V.; Selvadurai, A.P.B.; Zhao, Y.; Thiyagarajan, R.; Murugaraj, R. Room temperature ferromagnetism in $\mathrm{Mn}$ doped $\mathrm{ZnO}$ : Co nanoparticles by co-precipitation method. Physica B: Condensed Matter 2016, 481, 91-96, https://doi.org/10.1016/j.physb.2015.10.024.

9. Yakout, S.M.; El-Sayed, A.M. Synthesis, Structure, and Room Temperature Ferromagnetism of Mn and/or Co Doped ZnO Nanocrystalline. Journal of Superconductivity and Novel Magnetism 2016, 29, 1593-1599, https://doi.org/10.1007/s10948-016-3446-x.

10. de Almeida, V.M.; Mesquita, A.; de Zevallos, A.O.; Mamani, N.C.; Neves, P.P.; Gratens, X.; Chitta, V.A.; Ferraz, W.B.; Doriguetto, A.C.; Sabioni, A.C.S.; de Carvalho, H.B. Room temperature ferromagnetism promoted by defects at zinc sites in Mn-doped ZnO. Journal of Alloys and Compounds 2016, 655, 406-414, https://doi.org/10.1016/j.jallcom.2015.09.084.

11. Mote, V.D.; Purushotham, Y.; Dole, B.N. Structural, morphological, physical and dielectric properties of $\mathrm{Mn}$ doped $\mathrm{ZnO}$ nanocrystals synthesized by sol-gel method. Materials \& Design 2016, 96, 99-105, https://doi.org/10.1016/j.matdes.2016.02.016. 
12. Lian, X.; Li, Y.; Lv, T.; Zou, Y.; An, D.; Zhang, N. Preparation of ZnO nanoparticles by combustion method and their gas sensing properties. Electronic Materials Letters 2016, 12, 24-31, https://doi.org/10.1007/s13391-015-5293-5.

13. Ravichandran, K.; Karthika, K.; Sakthivel, B.; Jabena Begum, N.; Snega, S.; Swaminathan, K.; Senthamilselvi, V. Tuning the combined magnetic and antibacterial properties of $\mathrm{ZnO}$ nanopowders through Mn doping for biomedical applications. Journal of Magnetism and Magnetic Materials 2014, 358-359, 5055, https://doi.org/10.1016/j.jmmm.2014.01.008.

14. Liu, W.; Tang, X.; Tang, Z. Effect of oxygen defects on ferromagnetism of Mn doped ZnO. Journal of Applied Physics 2013, 114, https://doi.org/10.1063/1.4823774.

15. Luo, X.; Lee, W.-T.; Xing, G.; Bao, N.; Yonis, A.; Chu, D.; Lee, J.; Ding, J.; Li, S.; Yi, J. Ferromagnetic ordering in Mn-doped $\mathrm{ZnO}$ nanoparticles. Nanoscale Research Letters 2014, 9, https://doi.org/10.1186/1556-276X-9-625.

16. Shatnawi, M.; Alsmadi, A.M.; Bsoul, I.; Salameh, B.; Mathai, M.; Alnawashi, G.; Alzoubi, G.M.; Al-Dweri, F.; Bawa'aneh, M.S. Influence of Mn doping on the magnetic and optical properties of $\mathrm{ZnO}$ nanocrystalline particles. Results in Physics 2016, 6, 1064-1071, https://doi.org/10.1016/j.rinp.2016.11.041.

17. Acheson, R.M. An introduction to the chemistry of heterocyclic compounds. John Wiley \& Sons Publishers, 1976.

18. Kulkarn, S.S. Optical and structural properties of zinc oxide nanoparticles. International Journal of Advanced Research in Physical Science 2015, 2, 14- 18.

19. Vanaja, A.; Karumuri, S.R. Effect of Co Doping on Structural and Optical Properties of Zinc Oxide Nanoparticles Synthesized by Sol-Gel Method. Advances in Nanoparticles 2016, 05, 83-89, https://doi.org/10.4236/anp.2016.51010.

20. Tsuzuki, T.; Smith, Z.; Parker, A.; He, R.; Wang, X. Photocatalytic Activity of Manganese-Doped ZnO Nanocrystalline Powders. Journal of the Australian Ceramic Society 2009, 45, 58-62.

21. Leyva, E.; Montalvo, C.; Moctezuma, E.; Leyva, S. Photocatalytic degradation of pyridine in water solution using $\mathrm{ZnO}$ as an alternative catalyst to TiO2. Journal of Ceramic Processing Research 2008, 9, 455-462.

22. Monajjemi, M.; Heshmat, M.; Aghaei, H.; Ahmadi, R.; Zare, K. Solvent effect on N-14 NMR shielding of glycine, serine, leucine, and threonine: Comparison between chemical shifts and energy versus dielectric constant. Bulletin of the chemical society of ethiopia 2007, 21, 111-116, https://doi.org/10.4314/bcse.v21i1.61387.

23. Monajjemi, M.; Honaparvar, B.; Khalili Hadad, B.; Ilkhani, A.; Mollaamin, F. Thermo-Chemical Investigation and NBO Analysis of Some anxileotic as Nano- Drugs. African journal of pharmacy and pharmacology 2010, 4, 521-529.

24. Monajjemi, M.; Mollaamin, F. Molecular Modeling Study of Drug-DNA Combined to Single Walled Carbon Nanotube. Journal of Cluster Science 2012, 23, 259-272,https://doi.org/10.1007/s10876-011-0426-y.

25. 25.Mahdavian, L.; Monajjemi, M. Alcohol sensors based on SWNT as chemical sensors: Monte Carlo and Langevin dynamics simulation. Microelectronics journal 2010, 41, 142-149, https://doi.org/10.1016/j.mejo.2010.01.011.

26. Monajjemi, M. Liquid-phase exfoliation (LPE) of graphite towards graphene: An ab initio study. Journal of Molecular Liquids 2017, 230, 461-472, https://doi.org/10.1016/j.molliq.2017.01.044.

27. Mahdavian, L.; Monajjemi, M.; Mangkorntong, N. Sensor response to alcohol and chemical mechanism of carbon nanotube gas sensors Fullerenes Nanotubes and Carbon Nanostructures 2009, 17, 484-495, https://doi.org/10.1080/15363830903130044.

28. Monajjemi, M.; Najafpour, J. Charge density discrepancy between NBO and QTAIM in single-wall armchair carbon nanotubes. Fullerenes Nanotubes and Carbon Nano structures 2014, 22, 575-594, https://doi.org/10.1080/1536383X.2012.702161.

29. Monajjemi, M.; Hosseini, M.S. Non bonded interaction of B16 N16 nano ring with copper cations in point of crystal fields. Journal of Computational and Theoretical Nanoscience 2013, 10, 2473-2477.

30. Monajjemi, M.; Mahdavian, L.; Mollaamin, F. Characterization of nanocrystalline silicon germanium film and nanotube in adsorption gas by Monte Carlo and Langevin dynamic simulation. Bulletin of the Chemical Society of Ethiopia 2008, 22, 277-286, https://doi.org/10.4314/bcse.v22i2.61299.

31. Lee, V.S.; Nimmanpipug, P.; Mollaamin, F.; Thanasanvorakun, S.; Monajjemi, M. Investigation of single wall carbon nanotubes electrical properties and normal mode analysis: Dielectric effects. Russian Journal of Physical Chemistry A 2009, 83, 2288-2296, https://doi.org/10.1134/S0036024409130184.

32. Mollaamin, F.; Najafpour, J.; Ghadami, S.; Akrami, M.S.; Monajjemi, M. The electromagnetic feature of B $\mathrm{N} \mathrm{H}(\mathrm{x}=0,4,8,12,16$, and 20) nano rings:Quantum theory of atoms in molecules/NMR approach. Journal of Computational and Theoretical Nanoscience 2014, 11, 1290-1298.

33. Monajjemi, M.; Mahdavian, L.; Mollaamin, F.; Honarparvar, B. Thermodynamic investigation of enolketo tautomerism for alcohol sensors based on carbon nanotubes as chemical sensors. Fullerenes Nanotubes and Carbon Nanostructures 2010, 18, 45-55, https://doi.org/10.1080/15363830903291564.

34. Monajjemi, M.; Ghiasi, R.; Seyed, S.M.A. Metal-stabilized rare tautomers: N4 metalated cytosine $(\mathrm{M}=\mathrm{Li}$, $\mathrm{Na}, \mathrm{K}, \mathrm{Rb}$ and $\mathrm{Cs}$ ), theoretical views. Applied Organometallic Chemistry 2003, 17, 635-640, https://doi.org/10.1002/aoc.469. 
35. Ilkhani, A.R.; Monajjemi, M. The pseudo Jahn-Teller effect of puckering in pentatomic unsaturated rings C $\mathrm{AE}, \mathrm{A}=\mathrm{N}, \mathrm{P}, \mathrm{As}, \mathrm{E}=\mathrm{H}, \mathrm{F}, \mathrm{Cl}$.Computational and Theoretical Chemistry 2015, 1074, 19-25, http://dx.doi.org/10.1016\%2Fj.comptc.2015.10.006.

36. Monajjemi, M.; Naderi, F.; Mollaamin, F.; Khaleghian, M. Drug design outlook by calculation of second virial coefficient as a nano study. Journal of the Mexican Chemical Society 2012, 56, 207-211, https://doi.org/10.29356/jmcs.v56i2.323.

37. Monajjemi, M.; Bagheri, S.; Moosavi, M.S. Symmetry breaking of B2N(-,0,+): An aspect of the electric potential and atomic charges. Molecules 2015, 20, 21636-21657, https://doi.org/10.3390/molecules201219769.

38. Monajjemi, M.; Mohammadian, N.T. S-NICS: An aromaticity criterion for nano molecules. Journal of Computational and Theoretical Nanoscience 2015, 12, 4895-4914, https://doi.org/10.1166/jctn.2015.4458.

39. Monajjemi, M.; Ketabi, S.; Hashemian, Z.M.; Amiri, A. Simulation of DNA bases in water: Comparison of the Monte Carlo algorithm with molecular mechanics force fields. Biochemistry (Moscow) 2006, 71, 1-8, https://doi.org/10.1134/s0006297906130013.

40. Mollaamin, F.; Monajjemi, M.; Mehrzad, J. Molecular Modeling Investigation of an Anti-cancer Agent Joint to SWCNT Using Theoretical Methods. Fullerenes nanotubes and carbon nanostructures 2014, 22, 738751, https://doi.org/10.1080/1536383X.2012.731582.

41. Monajjemi, M.; Ketabi, S.; Amiri, A. Monte Carlo simulation study of melittin: protein folding and temperature ependence, Russian journal of physical chemistry 2006, 80, S55-S62, https://doi.org/10.1134/S0036024406130103.

42. Monajjemi, M; Heshmata, M; Haeria, H.H. QM/MM model study on properties and structure of some antibiotics in gas phase: Comparison of energy and NMR chemical shift. Biochemistry-moscow 2006, 71, S113-S122, https://doi.org/10.1134/S0006297906130190.

43. Monajjemi, M.; Heshmat, M.; Haeri, H.H.; Kaveh, F. Theoretical study of vitamin properties from combined QM-MM methods: Comparison of chemical shifts and energy.Russian journal of physical chemistry 2006, 80, 1061-1068, https://doi.org/10.1134/S0036024406070119.

44. Monajjemi, M.; Honarparvar, B.; Haeri, H.H.; Heshmat, M. An ab initio quantum chemical investigation of solvent-induced effect on N-14-NQR parameters of alanine, glycine, valine, and serine using a polarizable continuum model. Russian journal of physical chemistry 2006, 80, S40-S44, https://doi.org/10.1134/S0036024406130073.

45. Monajjemi, M.; Farahani, N.; Mollaamin, F. Thermodynamic study of solvent effects on nanostructures: phosphatidylserine and phosphatidylinositol membranes. Physics and chemistry of liquids 2012, 50, 161172, https://doi.org/10.1080/00319104.2010.527842.

46. Monajjemi, M.; Ahmadianarog, M. Carbon Nanotube as a Deliver for Sulforaphane in Broccoli Vegetable in Point of Nuclear Magnetic Resonance and Natural Bond Orbital Specifications. Journal of computational and theoretical nanoscience 2014, 11, 1465-1471, https://doi.org/10.1166/jctn.2014.3519.

47. Monajjemi, M.; Ghiasi, R.; Ketabi, S.; Passdar, H.; Mollaamin, F. A Theoretical Study of Metal-Stabilised Rare Tautomers Stability: N4 Metalated Cytosine (M=Be2+, Mg2+, Ca2+, Sr2+ and $\mathrm{Ba} 2+)$ in Gas Phase and Different Solvents. Journal of Chemical Research 2004, 2004, 11-18, https://doi.org/10.3184/030823404323000648.

48. Monajjemi, M.; Honarparvar, B.; Nasseri, S.M.; Khaleghian, M. NQR and NMR study of hydrogen bonding interactions in anhydrous and monohydrated guanine cluster model: A computational study. Journal of structural chemistry 2009, 50, 67-77, https://doi.org/10.1007/s10947-009-0009-z.

49. Monajjemi, M.; Aghaie, H.; Naderi, F. Thermodynamic study of interaction of TSPP, CoTsPc, and FeTsPc $\begin{array}{lllll}\text { with calf thymus DNA. Biochemistry-Moscow 2007, } & \text { 72, }\end{array}$ https://doi.org/10.1134/S0006297907060089.

50. Pirouzfar, V.; Omidkhah, M. Mathematical modeling and optimization of gas transport through carbon molecular sieve membrane and determining the model parameters using genetic algorithm. Iranian Polymer Journal 2016, 25, 203-212, https://doi.org/10.1007/s13726-016-0414-z.

51. Kianfar, E.; Pirouzfar, V.; Sakhaeinia, H. An experimental study on absorption/stripping CO2 using monoethanol amine hollow fiber membrane contactor. Journal of the Taiwan Institute of Chemical Engineers 2017, 80, 954-962, https://doi.org/10.1016/j.jtice.2017.08.017.

52. Saleh, S.; Pirouzfar, V.; Alihosseini, A. Performance analysis and development of a refrigeration cycle through various environmentally friendly refrigerants. Journal of Thermal Analysis and Calorimetry 2018, 136, 1817-1830, https://doi.org/10.1007/s10973-018-7809-3.

53. Zamankhan, F.; Pirouzfar, V.; Ommi, F.; Valihesari, M. Investigating the effect of MgO and CeO2 metal nanoparticle on the gasoline fuel properties: empirical modeling and process optimization by surface methodology. Environ Sci Pollut Res 2018, 25, 22889-22902, https://doi.org/10.1007/s11356-018-2066-3.

54. Zamankhan, F.; Pirouzfar, V.; Ommi, F.; Valihesari, M. Investigating the effect of MgO and CeO2 metal nanoparticle on the gasoline fuel properties: empirical modeling and process optimization by surface methodology. Environ Sci Pollut Res 2018, 25, 22889-22902, https://doi.org/10.1007/s11356-018-2066-3. 
55. Valihesari, M.; Pirouzfar, V.; Ommi, F.; Zamankhan, F. Investigating the effect of Fe2O3 and TiO2 nanoparticle and engine variables on the gasoline engine performance through statistical analysis. Fuel 2019, 254, https://doi.org/10.1016/j.fuel.2019.115618.

56. Saeedi Dehaghani, A.H.; Pirouzfar, V. Investigation on the Effect of Microalgae Chlorella sp. and Spirulina on Biodiesel Production. Petroleum Chemistry 2018, 58, 702-708, https://doi.org/10.1134/S0965544118080042.

57. Barza, A.; Mehri, B.; Pirouzfar, V. Mathematical Modeling of Ethane Cracking Furnace of Olefin Plant with Coke Formation Approach. International Journal of Chemical Reactor Engineering 2018, 16, https://doi.org/10.1515/ijcre-2017-0243.

58. Hashemzehi, M.; Pirouzfar, V.; Nayebzadeh, H.; Alihosseini, A. Effect of synthesizing conditions on the activity of zinc-copper aluminate nanocatalyst prepared by microwave combustion method used in the esterification reaction. Fuel 2020, 263, https://doi.org/10.1016/j.fuel.2019.116422.

59. Lu, T.; Chen, F. Calculation of Molecular Orbital Composition. Acta Chimica Sinica-Chinese Edition- 2011, 69, 2393-2406.

60. Lu, T.; Chen, F. Quantitative analysis of molecular surface based on improved Marching Tetrahedra algorithm. Journal of Molecular Graphics and Modelling 2012, 38, 314-323, https://doi.org/10.1016/j.jmgm.2012.07.004.

61. Lu, T.; Chen, F. Multiwfn: A multifunctional wavefunction analyzer. Journal of Computational Chemistry 2012, 33, 580-592, https://doi.org/10.1002/jcc.22885.

62. Raza, A.; Hayat, U.; Rasheed, T.; Bilal, M.; Iqbal, H.M.N. "Smart” materials-based near-infrared lightresponsive drug delivery systems for cancer treatment: A review. Journal of Materials Research and Technology 2019, 8, 1497-1509, https://doi.org/10.1016/j.jmrt.2018.03.007.

63. Lee, N.-Y.; Ko, W.-C.; Hsueh, P.-R. Nanoparticles in the Treatment of Infections Caused by MultidrugResistant Organisms. Frontiers in pharmacology 2019, 10, 1153-1153, https://doi.org/10.3389/fphar.2019.01153.

64. Aghebati-Maleki, A.; Dolati, S.; Ahmadi, M.; Baghbanzhadeh, A.; Asadi, M.; Fotouhi, A.; Yousefi, M.; Aghebati-Maleki, L. Nanoparticles and cancer therapy: Perspectives for application of nanoparticles in the treatment of cancers. Journal of Cellular Physiology 2020, 235, 1962-1972, https://doi.org/10.1002/jcp.29126.

65. Elbialy, N.S.; Fathy, M.M.; Al-Wafi, R.; Darwesh, R.; Abdel-dayem, U.A.; Aldhahri, M.; Noorwali, A.; Alghamdi, A.A. Multifunctional magnetic-gold nanoparticles for efficient combined targeted drug delivery and interstitial photothermal therapy. International Journal of Pharmaceutics 2019, 554, 256-263, https://doi.org/10.1016/j.ijpharm.2018.11.021.

66. Jia, T.; Xu, J.; Dong, S.; He, F.; Zhong, C.; Yang, G.; Bi, H.; Xu, M.; Hu, Y.; Yang, D.; Yang, P.; Lin, J. Mesoporous cerium oxide-coated upconversion nanoparticles for tumor-responsive chemo-photodynamic therapy and bioimaging. Chemical Science 2019, 10, 8618-8633, https://doi.org/10.1039/C9SC01615E.

67. Amirshaghaghi, A.; Yan, L.; Miller, J.; Daniel, Y.; Stein, J.M.; Busch, T.M.; Cheng, Z.; Tsourkas, A. Chlorin e6-Coated Superparamagnetic Iron Oxide Nanoparticle (SPION) Nanoclusters as a Theranostic Agent for Dual-Mode Imaging and Photodynamic Therapy. Scientific Reports 2019, 9, https://doi.org/10.1038/s41598019-39036-1.

68. Laurenti, M.; Garino, N.; Canavese, G.; Hernandéz, S.; Cauda, V. Piezo- and Photocatalytic Activity of Ferroelectric ZnO:Sb Thin Films for the Efficient Degradation of Rhodamine- $\beta$ dye Pollutant. ACS Applied Materials \& Interfaces 2020, 12, 25798-25808, https://doi.org/10.1021/acsami.0c03787.

69. Lops, C.; Ancona, A.; Di Cesare, K.; Dumontel, B.; Garino, N.; Canavese, G.; Hérnandez, S.; Cauda, V. Sonophotocatalytic degradation mechanisms of Rhodamine B dye via radicals generation by micro- and nanoparticles of ZnO. Applied Catalysis B: Environmental 2019, 243, 629-640, https://doi.org/10.1016/j.apcatb.2018.10.078.

70. Garino, N.; Limongi, T.; Dumontel, B.; Canta, M.; Racca, L.; Laurenti, M.; Castellino, M.; Casu, A.; Falqui, A.; Cauda, V. A Microwave-Assisted Synthesis of Zinc Oxide Nanocrystals Finely Tuned for Biological Applications. Nanomaterials 2019, 9, https://doi.org/10.3390/nano9020212.

71. Garino, N.; Sanvitale, P.; Dumontel, B.; Laurenti, M.; Colilla, M.; Izquierdo-Barba, I.; Cauda, V.; ValletRegì, M. Zinc oxide nanocrystals as a nanoantibiotic and osteoinductive agent. RSC Advances 2019, 9, 11312-11321, https://doi.org/10.1039/C8RA10236H.

72. Laurenti, M.; Lamberti, A.; Genchi, G.G.; Roppolo, I.; Canavese, G.; Vitale-Brovarone, C.; Ciofani, G.; Cauda, V. Graphene Oxide Finely Tunes the Bioactivity and Drug Delivery of Mesoporous ZnO Scaffolds. ACS Applied Materials \& Interfaces 2019, 11, 449-456, https://doi.org/10.1021/acsami.8b20728.

73. Laurenti, M.; Lamberti, A.; Genchi, G.G.; Roppolo, I.; Canavese, G.; Vitale-Brovarone, C.; Ciofani, G.; Cauda, V. Graphene Oxide Finely Tunes the Bioactivity and Drug Delivery of Mesoporous ZnO Scaffolds. ACS Applied Materials \& Interfaces 2019, 11, 449-456, https://doi.org/10.1021/acsami.8b20728.

74. Vighetto, V.; Ancona, A.; Racca, L.; Limongi, T.; Troia, A.; Canavese, G.; Cauda, V. The Synergistic Effect of Nanocrystals Combined With Ultrasound in the Generation of Reactive Oxygen Species for Biomedical Applications. Front Bioeng Biotechnol 2019, 7, https://doi.org/10.3389/fbioe.2019.00374. 
75. Dumontel, B.; Susa, F.; Limongi, T.; Canta, M.; Racca, L.; Chiodoni, A.; Garino, N.; Chiabotto, G.; Centomo, M.L.; Pignochino, Y.; Cauda, V. ZnO nanocrystals shuttled by extracellular vesicles as effective Trojan nano-horses against cancer cells. Nanomedicine (London, England) 2019, 14, 2815-2833, https://doi.org/10.2217/nnm-2019-0231.

76. Racca, L.; Limongi, T.; Vighetto, V.; Dumontel, B.; Ancona, A.; Canta, M.; Canavese, G.; Garino, N.; Cauda, V. Zinc Oxide Nanocrystals and High-Energy Shock Waves: A New Synergy for the Treatment of Cancer Cells. Frontiers in bioengineering and biotechnology 2020, 8, https://doi.org/10.3389/fbioe.2020.00577.

77. Kayani, Z.N.; Bashir, H.; Riaz, S.; Naseem, S. Optical properties and antibacterial activity of V doped ZnO used in solar cells and biomedical applications. Materials Research Bulletin 2019, 115, 121-129, https://doi.org/10.1016/j.materresbull.2019.03.016.

78. Han, C.; Duan, L.; Zhao, X.; Hu, Z.; Niu, Y.; Geng, W. Effect of Fe doping on structural and optical properties of $\mathrm{ZnO}$ films and nanorods. Journal of Alloys and Compounds 2019, 770, 854-863, https://doi.org/10.1016/j.jallcom.2018.08.217.

79. Malik, R.; Tomer, V.K.; Mishra, Y.K.; Lin, L. Functional gas sensing nanomaterials: A panoramic view. Applied Physics Reviews 2020, 7, https://doi.org/10.1063/1.5123479.

80. Barui, S.; Gerbaldo, R.; Garino, N.; Brescia, R.; Laviano, F.; Cauda, V. Facile Chemical Synthesis of Doped ZnO Nanocrystals Exploiting Oleic Acid. Nanomaterials 2020, 10, https://doi.org/10.3390/nano10061150.

81. Swati; Verma, R.; Chauhan, A.; Shandilya, M.; Li, X.; Kumar, R.; Kulshrestha, S. Antimicrobial potential of ag-doped $\mathrm{ZnO}$ nanostructure synthesized by the green method using moringa oleifera extract. Journal of Environmental Chemical Engineering 2020, 8, https://doi.org/10.1016/j.jece.2020.103730.

82. Namgung, G.; Ta, Q.T.H.; Yang, W.; Noh, J.-S. Diffusion-Driven Al-Doping of ZnO Nanorods and Stretchable Gas Sensors Made of Doped ZnO Nanorods/Ag Nanowires Bilayers. ACS Applied Materials \& Interfaces 2019, 11, 1411-1419, https://doi.org/10.1021/acsami.8b17336.

83. Tsai, Y.-T.; Chang, S.-J.; Ji, L.-W.; Hsiao, Y.-J.; Tang, I.T. Fast Detection and Flexible Microfluidic pH Sensors Based on Al-Doped ZnO Nanosheets with a Novel Morphology. ACS Omega 2019, 4, 19847-19855, https://doi.org/10.1021/acsomega.9b02778.

84. Xiong, Y.; Yi, W.Y.; Yang, G.W.; Yang, Y.H. Elongated hexagonal ZnO micro-fence optical resonator. Current Applied Physics 2019, 19, 984-986, https://doi.org/10.1016/j.cap.2019.05.014.

85. Samanta, A.; Goswami, M.N.; Mahapatra, P.K. Fe-doped ZnO nanoparticles as novel photonic and multiferroic semiconductor. Materials Chemistry and Physics 2020, 240, https://doi.org/10.1016/j.matchemphys.2019.122180.

86. Isik, M.; Gasanly, N.M. Gd-doped ZnO nanoparticles: Synthesis, structural and thermoluminescence properties. Journal of Luminescence 2019, 207, 220-225, https://doi.org/10.1016/j.jlumin.2018.11.022.

87. Chandrasekaran, K.; Varaprasad, K.; Venugopal, S.K.; Arun, L.; Hameed, A.S.H. Synergistic Antibacterial Effect of the Magnesium-Doped ZnO Nanoparticles with Chloramphenicol. BioNanoScience 2020, 10, 106111, https://doi.org/10.1007/s12668-019-00696-y.

88. Cobianu, C.; Dumbravescu, N.; Serban, B.-C.; Buiu, O.; Romanitan, C.; Comanescu, F.; Danila, M.; Marinescu, R.; Avramescu, V.; Ionescu, O. Sonochemically synthetized ZnO-Graphene nanohybrids and its characterization. Reviews On Advanced Materials Science 2020, 59, 176-187, https://doi.org/10.1515/rams2020-0013. 